\title{
Effectiveness of a Program Based on Instructional Trip on Developing Some Thinking Skills among Elementary Children with Learning Difficulty
}

\author{
Dr. Abdallah Makhadmah \\ Head of Social Services, Ministry of Justice, the Hashemite Kingdom of Jordan
}

\begin{abstract}
The purpose of the present study was to identify the effectiveness of a program based on instruction trip on developing some thinking skills among elementary children with learning difficulties. A quasi experimental research design was used due to appropriateness with the nature of this study. Participants were (60) students assigned to experimental $(n=30)$ and control groups $(n=30)$. The instruments were tested for validity and reliability and applied to analyze data. Results showed differences between the experimental and control groups on posttest measurement with differences being in favor of the experimental group. Similarly, there were differences between pretest and posttest measurements for both groups on developing some thinking skills where $t$ value was (7.306 and 3.08) for the experimental and control groups respectively and statistically significant at (0.000) level in favor of posttest measurement. As for the program based on instructional trip used to develop some thinking skills, results demonstrated differences by group at significance level (0.000) in favor of the experimental group; and no differences in developing some thinking skills on covariate posttest measurement (0.691), confirming equivalence between both groups on posttest measurement.
\end{abstract}

Keywords: training program, instructional trip, thinking skills

DOI: $10.7176 /$ RHSS/10-14-05

Publication date:July $31^{\text {st }} 2020$

\section{Introduction}

Instructional trip is one of novel teaching styles that utilize psychological and educational approaches such as meaningful learning, enriched learning, mastery learning and teaching for understanding (Zaitoun, 2003).

The instructional trip used in the current study was chosen because it stimulates learning, evoke motivation and engage the attention of learners. Since the aim of the present study was to develop some thinking skills that depend on many intricate mental processes that take place in brain like synthesis, deduction, etc., so the field trip takes learners further out of the classroom, and engage learners to develop their thinking skills As an instructional strategy, the field trip model used in the current study includes learning activities inside and outside classroom aiming at mastery of learning outcomes, and creates in learners enjoyment and the motivation to learn by engaging their attention. In this approach, an effective teaching is one that stimulates learning, creates understanding and mastery, and deepens learning. So, the current study sought to investigate instructional trip models (teaching for undercutting, mastery learning, meaningful learning and enriched learning) for purpose of developing thinking among elementary children.

Thinking skills widely diversify, some of which relates with psychological and education aspects, for example one's desire to learn about something, and reach specific outcomes, or one's determination to reach specific result or ability to achieve outcomes required for certain task. Another kind of skills relate with perception and testing information and measured by child's ability to store, retrieve and recall information on time, as well as attention and accurate observation. However, such diversified skills need to be dealt with using a strategy that is capable to develop and sharpen the skills, especially if we were to deal with children from different age groups. The current study is focused on the elementary stage, and children in this group tend to play and have expanded imagination. Taking this into account, the researcher used the instructional trip strategy in the current study to attract their attention and engage them in the learning so as to develop some of their thinking skills. the study addresses and tries to answer the following question:

"To what extent was the effectiveness of a program based on instructional trip in developing some thinking skills among elementary children with learning difficulties?"

\section{Literature Review}

Al-Otaibi (2017) sought to identify the effect of a training program designed based on instructional trip on developing English reading apprehension skills by gifted students. Specifically, the study intended to find out whether there were statistically significant differences between performance of students exposed to the training program compared with those did not expose to the program. Participants were (60) students attending first secondary grade level at a secondary school in Al Haditha, Al Qrayat and were intentionally assigned to experimental and control groups. To achieve the study goals, the experimental group was exposed to a training 
program based on WebQuest, whereas the control group received no training. Both groups were administered pretest measurement prior to the training program. To determine the effect of the training program, both groups received posttest measurement at the end of the training. To answer study questions, and data analysis, the Statistical Program for Social Sciences SPSS including MANCOVA analysis was used. Results showed statistically significant differences between performance of the experimental compared with control group on posttest reading apprehension on all test dimensions (literal, interpretive, and critical), where the experimental group members outperformed their counterparts in the control group. In light of earlier results, some recommendations were presented.

Mohammad (2017) explored effectiveness of WebQuest philosophy teaching strategy on developing future thinking skills and motivation to achievement among secondary school students. The researcher used the descriptive statistics and experimental design on a sample of 30 students attending the second secondary grade level at Um Al-Muminen Secondary School at the first semester of the academic year 2016/2017. Instruments used included future thinking skills checklist, WebQuest, Teacher's Manual, Future Thinking Skills Test, Motivation to Achievement Scale. The study addressed the topic over two themes: first: WebQuest strategy and focused on a number of points such as WebQuest strategy concept, WebQuest strategy design criteria, stages of WebQuest strategy (introduction, tasks, processes, procedures, resources, assessment, conclusion, results and teacher's profile), types of WebQuest strategy, teacher's role in webQuest strategy and importance of WebQuest strategy. The second theme was focused on future thinking skills in terms of concept of future thinking skills, basics of future thinking, future thinking skills importance of developing future thinking skills. The study concluded with a number of results most importantly is that mean score of experimental group students was higher on future thinking skills test compared to control groups students, meaning greater effect size. The author recommended greater emphasis on developing future thinking skills and help students acquire them. Further studies on the effectiveness of using WebQuest strategy in philosophy teaching on developing decision-making skills and attitudes to this subject among secondary school students. Rushdi \& Saleh (2016) aimed at measuring effectiveness of using virtual reality WebQuest in developing creative skills among vocation students at the Faculty of Education. The study adopted the quasi experimental design. The sample consisted of student population at Faculty of Education, Halwan University, in the Industrial Education Section, majoring ceramic industries, woodwork industries, Second Batch. The instruments used included the questionnaire survey to identify the WebQuest tools most appropriate to develop creative skills. To determine what skills need to be developed among vocational educational students, Creative Skills Checklist was developed. Torrance Scale for Creative Skills was also used. The study addressed the concept, importance, types, and features of virtual reality webQuest. In addition, the study addressed creative thinking skills, contributing factors and value of creative thinking. The study found that 3D-figures was impressive because it presents art objects in three dimensions (length, width and depth), which enable students interact with art objects. The study stressed that using the 3D-webquest simulates figures with major features of the art objects in the Islamic era. The study recommended adoption of the WebQuest model developed by the researcher and employ it in history teaching. The study called for paying greater attention to technological tools including virtual field trips for students to acquire artistic skills. Mahgoub (20140 conducted a study to explore the relationship between field trips and potential benefits for students in terms of artistic skills and creativity. Specifically, the study sought to answer the following questions: Are there positive effects of field trips on student thinking and creative practices in artistic tasks? The sample consisted of 60 third-level students (2011-2012) from Rufaida Primary School, one of African Council Schools in Sudan. The study used descriptive statistics, analyses and experimental methods to explore the advantages of the field trip to natural and artificial environments and its role in evoking students' creativity and practices in the artistic tasks. Results showed large intergroup difference among students working on artistic tasks between experimental compared with control groups. The study concluded that field trips to natural and artificial environments was helpful in student learning and enhanced student artistic creativity and practices. The study contributed with valuable recommendations to educators and teachers, especially Arts educators, and encouraged inserting field trips to natural and artificial environments in the Arts Education Curriculum. Ikpere \& Fenice (2007) conducted a study aimed at identifying multitasking in WebQuest strategy to facilitate developing literacy skills and scientific thinking skills among primary fifth graders. The study concluded that using WebQuest contributed to increased student learning, acquiring scientific thinking skills and increased student-student collaboration and student-teacher communication, and increased their motivation to research. In the same direction, Li \& Yang (2007) sought to identify effectiveness of employing WebQuest in developing scientific thinking skills and increase English achievement by elementary students. The study found that using WebQuest increased achievement by 6th graders and developed their scientific thinking skills and enhanced their motivation. Burke, Guffey, Colter \& Richil (2004) sought to evaluate effectiveness of using WebQest strategy in teaching biology content to secondary students in comparison with using biology practical presentations. The study found that WebQuest strategy was as effective as practical presentations, but students who studied at the computer lab had positive attitudes towards WebQuest strategy. Mitchell (2003) conducted as study for purpose of exploring the impact of using WebQuest as a teaching method depending on web search 
engines on improving learning and create positive attitudes towards the Internet among 8th graders. The study found that teaching depending on WebQuest increased student motivation to complete their tasks, developed their scientific thinking skills, improved their performance through answering specific questions on tasks, and provided them positive attitudes toward using the Internet. Ikepez (2003) investigated the effect of using multitasking through WebQuest to stimulate higher thinking skills in social studies topics among elementary 5th graders. The study concluded that working in small groups using WebQuest enhanced social communication and collaboration among students, deepened their understanding of the scientific content and created positive attitudes to browsing the Internet.

\section{Study Design}

A quasi experimental design with two experimental and control groups was used in the current study. The study design consists of nonequivalent or nonrandom groups with pre-posttest measurement, can be represented by the following diagram:

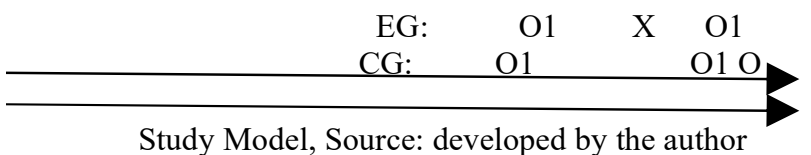

Where;

EG: Experimental Group

CG: Control Group

O1: thinking skills (pretest-posttest measurement)

$\mathrm{X}$ : Treatment: application of the instructional trip program

\subsection{Study Instrument}

The researcher used in the current study two instruments:

3.1.1 First: A program based on instructional trip applied on elementary students by adopting the following procedure:

- Determining the number of training sessions and time needed for each session.

- Setting a goal for each session and how to accomplish it.

- Observing the current performance level of children participating in the study.

- Evoke the motivation of children.

- Flexible and consistent implementation of the program on day-to-day basis give children the feeling of stability, disciplined, and allows for making modifications as necessary.

- Take advantage of the material available in the surrounding environment based on interests of children participating in the c current stud.

- A discussion was held between the researcher and participants for dialogue and share ideas as allowed by their capabilities.

- Concentrate on the rest intervals during program implementation (Al Aydi, 2011).

3.1.2 Second: Description of the Program

A series of organized training sessions that have specific timelines and designed based on the relevant literature and prior studies. The author managed the sessions for purpose of developing some thinking skills. The program consists of ten sessions determined by the author in light of a pilot study.

\subsection{Rationales behind the Program}

The rationales behind employing this strategy included that:

1. Knowledge exposure that doubled facts and information, and there have been calls to develop special skills need for children with learning difficulties.

2. Global interest with the importance of learning difficulties and how critical it is.

3. The program is practical and can be implemented based on theoretical bases to develop some thinking skills among elementary children with learning difficulties.

4. Association between theory and practice for purpose of bring about improvement in cognition and performance of participants in the instructional environment.

5. Encourage participation depending on some activities as participation of children with learning difficulties in the activities strengthens interrelationship between them (Abdulqader, 2012).

3.2.1 Goals of the Program

General Goal: Developing some thinking skills among elementary students with learning difficulties.

Specific Goals: Developing capabilities of individuals with learning difficulties, improve learning, encourage group working, and training individuals with learning difficulties to help each other. In addition to developing 
capabilities of children with learning difficulties on task organization and completion of a task initiated. 3.2.2 Assessment of the Program:

Assessment refers to the "process of making judgmental opinion of the value of something, a person or subjects. It implies improvement, modification and development that depend on such judgements". The meaning is that the assessment process intends to evaluate how successful was the suggested program in achieving its general goals designed to achieve. The purpose from current program assessment include:

Ensure appropriateness of activities to needs of children with learning difficulties.

Ensure integrity and coherence of content elements. Check logical sequence of the activities presented within each module. Verify inclusiveness of the educational activities inserted to the behavioral aspects of cognition, attitudes and skills (Al Thbeiti, 2011).

\subsection{Content Validity}

To ensure validity, the researcher sent the program to a number of educational professors specialized in special education, counseling and educational psychology for judging content validity and appropriateness to the population, specifically designed to be used with, check adequacy of time intervals, and usability of session design procedures.

\subsubsection{Thinking Skills:}

To measure the effect of the applying the program based on the instructional trip, the researcher investigated development of thinking skills among the elementary students participating in the current study. The psychometric properties of the program were ensured for purpose of relying on its in assessing improvement in thinking skills of elementary children with learning difficulties.

\subsection{Validity of the Instrument}

To ensure validity, the instrument was sent to a group of specialized and experienced judges for validation. Their notes were taken into account and the instrument was modified accordingly in line with study goals.

\subsection{Procedures:}

- The necessary official approvals were duly obtained.

- Participants were randomly assigned to both experimental and control groups.

- A program based on the instructional trip program was applied aiming at developing some thinking skills among elementary students with learning difficulties as a pretest of the experimental and control group members.

- The instructional trip program was applied to the experimental group.

- Following the application, participants were administered thinking skills test to measure the thinking skills among elementary students with learning difficulties and applied as posttest.

- Appropriate statistical analyses were conducted.

- Explanation of results, discussion, conclude recommendations based on the study results.

\subsection{Statistical Methods}

To achieve the study goals and answer questions, means and standard deviations of respondent ratings in the experimental and control groups. Paired Samples Test was conducted for the experimental and control groups to identify differences on the pretest and posttest measurements.

\section{Results and Discussions}

First Question: "To what extent was the effectiveness of a program based on instructional trip in developing some thinking skills among elementary children with learning difficulties?"

To answer this question, means and standard deviations were computed for the pretest and posttest measurements on the experimental and control groups. Further, the Independent Sample T-Test was applied on the independent samples to reveal any differences between the two groups on pretest and posttest measurements as shown by the following table.

Similarly, Paired sample T-Test was applied on the paired samples to identify any differences between pretest and posttest means for each group to measure the effect on developing some thinking skills among elementary children with learning difficulties as shown by the following table. 
Table 1. Independent Sample T-Test to identify group equivalence in developing thinking skills on the pretest

\begin{tabular}{|c|c|c|c|c|c|c|}
\hline Domain & Group & $\mathrm{M}$ & SD & T Value & Freedom Degrees & $\alpha$ \\
\hline \multirow[t]{2}{*}{ Teaching for Understanding } & Control & 1.55 & 0.17 & \multirow[t]{2}{*}{1.641} & \multirow[t]{2}{*}{58} & \multirow[t]{2}{*}{.106} \\
\hline & Experimental & 1.62 & 0.15 & & & \\
\hline \multirow[t]{2}{*}{ Mastery Learning } & Control & 1.52 & 0.17 & \multirow[t]{2}{*}{0.77} & \multirow[t]{2}{*}{58} & \multirow[t]{2}{*}{.939} \\
\hline & Experimental & 1.52 & 0.16 & & & \\
\hline \multirow[t]{2}{*}{ Meaningful Learning } & Control & 1.37 & 0.14 & \multirow[t]{2}{*}{1.873} & \multirow[t]{2}{*}{58} & \multirow[t]{2}{*}{.066} \\
\hline & Experimental & 1.45 & 0.16 & & & \\
\hline \multirow[t]{2}{*}{ Teaching Thinking } & Control & 1.51 & 0.44 & \multirow[t]{2}{*}{.863} & \multirow[t]{2}{*}{58} & \multirow[t]{2}{*}{.392} \\
\hline & Experimental & 2.15 & 4.02 & & & \\
\hline \multirow[t]{2}{*}{ Enriched Learning } & Control & 1.38 & 0.16 & \multirow[t]{2}{*}{.728} & \multirow[t]{2}{*}{58} & \multirow[t]{2}{*}{.469} \\
\hline & Experimental & 1.41 & 0.19 & & & \\
\hline \multirow[t]{2}{*}{ Overall Scale } & Control & 1.47 & 0.13 & \multirow[t]{2}{*}{1.129} & \multirow[t]{2}{*}{58} & \multirow[t]{2}{*}{.264} \\
\hline & Experimental & 1.63 & 0.78 & & & \\
\hline
\end{tabular}

The table 1 shows poor t values and statistically insignificant at $(\alpha=0.05)$ on the posttest measurement, confirming equivalence between experimental and control groups on the posttest.

Independent Sample T-test results to identify differences between groups on developing thinking skills on posttest measurement $(\mathrm{n}=60)$

Table 1. Sample T-test results to identify differences between groups on developing thinking skills on posttest measurement

\begin{tabular}{|c|c|c|c|c|c|c|}
\hline Domain & Group & $\mathrm{M}$ & SD & T Value & Freedom Degrees & $\alpha$ \\
\hline \multirow[t]{2}{*}{ Teaching for Understanding } & Control & 1.23 & 0.16 & \multirow[t]{2}{*}{-3.176} & \multirow[t]{2}{*}{58} & \multirow[t]{2}{*}{.002} \\
\hline & Experimental & 1.37 & 0.17 & & & \\
\hline \multirow[t]{2}{*}{ Mastery Learning } & Control & 1.08 & 0.08 & \multirow[t]{2}{*}{13.810} & \multirow[t]{2}{*}{58} & \multirow[t]{2}{*}{.000} \\
\hline & Experimental & 1.43 & 0.12 & & & \\
\hline \multirow[t]{2}{*}{ Meaningful Learning } & Control & 1.22 & 013 & \multirow[t]{2}{*}{-2.816} & \multirow[t]{2}{*}{58} & \multirow[t]{2}{*}{.007} \\
\hline & Experimental & 1.30 & 0.10 & & & \\
\hline \multirow[t]{2}{*}{ Teaching Thinking } & Control & 1.10 & 0.11 & \multirow[t]{2}{*}{2.206} & \multirow[t]{2}{*}{58} & \multirow[t]{2}{*}{.031} \\
\hline & Experimental & 1.18 & 0.17 & & & \\
\hline \multirow[t]{2}{*}{ Enriched Learning } & Control & 1.14 & 0.13 & \multirow[t]{2}{*}{2.595} & \multirow[t]{2}{*}{58} & \multirow[t]{2}{*}{.012} \\
\hline & Experimental & 1.23 & 0.13 & & & \\
\hline \multirow[t]{2}{*}{ Overall Scale } & Control & 1.19 & 0.07 & \multirow[t]{2}{*}{-5.646} & \multirow[t]{2}{*}{58} & \multirow[t]{2}{*}{.000} \\
\hline & Experimental & 1.28 & 0.06 & & & \\
\hline
\end{tabular}

The previous table shows t value statistically significant at $(\alpha=0.05)$ between the experimental and control groups on the posttest measurement with differences being in favor of the experimental group; meaning that the thinking skills in the experimental group improved on the posttest compared with the control group. This result proves that program contributed to development of thinking skills among the elementary children with learning difficulties.

Paired Samples Test applied on the paired samples to identify differences on pretest and posttest of thinking skills for the experimental versus control group. 
Table 2. differences on pretest and posttest of thinking skills for the experimental versus control group

\begin{tabular}{|c|c|c|c|c|c|c|c|}
\hline Domain & Group & Measurement & $M$ & $S D$ & $\begin{array}{c}T \\
\text { Value }\end{array}$ & $\begin{array}{c}\text { Freedom } \\
\text { Degrees }\end{array}$ & $\alpha$ \\
\hline \multirow{4}{*}{$\begin{array}{l}\text { Teaching for } \\
\text { Understanding }\end{array}$} & \multirow[t]{2}{*}{ Control } & Pretest & 1.23 & 0.16 & \multirow[t]{2}{*}{9.352} & \multirow[t]{2}{*}{29} & \multirow[t]{2}{*}{.000} \\
\hline & & Posttest & 1.62 & 0.15 & & & \\
\hline & \multirow[t]{2}{*}{ Experimental } & Pretest & 1.37 & 0.17 & \multirow[t]{2}{*}{4.892} & \multirow[t]{2}{*}{29} & \multirow[t]{2}{*}{.000} \\
\hline & & Posttest & 1.55 & 0.17 & & & \\
\hline \multirow[t]{4}{*}{ Mastery Learning } & \multirow[t]{2}{*}{ Control } & Pretest & 1.08 & 0.08 & \multirow[t]{2}{*}{12.862} & \multirow[t]{2}{*}{29} & \multirow[t]{2}{*}{.000} \\
\hline & & Posttest & 1.52 & 0.17 & & & \\
\hline & \multirow[t]{2}{*}{ Experimental } & Pretest & 1.43 & 0.12 & \multirow[t]{2}{*}{2.684} & \multirow[t]{2}{*}{29} & \multirow[t]{2}{*}{0.013} \\
\hline & & Posttest & 1.52 & 0.16 & & & \\
\hline \multirow[t]{4}{*}{ Meaningful Learning } & \multirow[t]{2}{*}{ Control } & Pretest & 1.22 & 0.13 & \multirow[t]{2}{*}{5.261} & \multirow[t]{2}{*}{29} & \multirow[t]{2}{*}{.000} \\
\hline & & Posttest & 1.45 & 0.16 & & & \\
\hline & \multirow[t]{2}{*}{ Experimental } & Pretest & 1.30 & 0.10 & \multirow[t]{2}{*}{2.027} & \multirow[t]{2}{*}{29} & \multirow[t]{2}{*}{0.052} \\
\hline & & Posttest & 1.37 & 0.14 & & & \\
\hline \multirow[t]{4}{*}{ Teaching Thinking } & \multirow[t]{2}{*}{ Control } & Pretest & 1.18 & 0.17 & \multirow[t]{2}{*}{1.301} & \multirow[t]{2}{*}{29} & \multirow[t]{2}{*}{.204} \\
\hline & & Posttest & 2.15 & 4.02 & & & \\
\hline & \multirow[t]{2}{*}{ Experimental } & Pretest & 1.10 & 0.11 & 4.934 & 29 & .000 \\
\hline & & Posttest & 1.51 & 0.44 & & & \\
\hline Enriched Learning & Control & Pretest & 1.23 & 0.13 & 4.180 & 29 & .000 \\
\hline & & Posttest & 1.41 & 0.19 & & & \\
\hline & Experimental & Pretest & 1.14 & 0.13 & 7.180 & 29 & .000 \\
\hline & & Posttest & 1.38 & 0.16 & & & \\
\hline Overall Scale & Control & Pretest & 1.19 & 0.07 & 3.080 & 29 & .005 \\
\hline & & Posttest & 1.63 & 0.78 & & & \\
\hline & Experimental & Pretest & 1.28 & 0.06 & 7.306 & 29 & .000 \\
\hline & & Posttest & 1.47 & 0.13 & & & \\
\hline
\end{tabular}

The above table shows statistically significant differences on the pretest and posttest for both groups on developing thinking skills, where (t) value for the experimental group was at (7.306), and significant at $(0.000)$ with differences being in favor of the posttest measurement. Comparatively, $(\mathrm{t})$ value for the control group was (3.080) and significant at (0.000) with differences being in favor of the posttest measurement.

Results demonstrate perceivable increase from (3.08) to (7.306), implying that the experimental group exposed to picture story program outperformed the control group and developed thinking skills.

To identify the effectiveness of using a program based on instructional trip on developing some thinking skills among elementary children with learning difficulties ANCOVA analysis test was applied and results are shown by the following table.

ANCOVA test results to identify differences between groups in developing thinking skills on the posttest as covariate

Table 3. Differences between groups in developing thinking skills on the posttest as covariate

\begin{tabular}{|l|l|l|l|l|l|}
\hline & Total Squares & Freedom Degrees & Means Squares & F Value & Statistical Significance \\
\hline Group & 0.127 & 1 & 0.127 & 31.392 & .000 \\
\hline Covariate & 0.001 & 1 & 0.001 & 0.160 & 0.691 \\
\hline Error & 0.230 & 57 & 0.004 & & \\
\hline Adjusted Error & 0.358 & 59 & & & \\
\hline
\end{tabular}

The table above shows statistically significant differences at (0.05) by group variable, where differences were in favor of the experimental group. Results also showed no difference in thinking skills on the pretest confirming equivalency between the two groups on the pretest measurement.

This result implies that the perceived improvement in the experimental group was caused by the effect of the instructional story program with statistical significance $(0.691)$ on the covariate pretest compared with $(0.000)$ for the whole group indicating positive effect of the program for students.

\section{References}

Al Otaibi, Meteb. (2017). The Effect of Cognitive Trips-Based Training Program on Developing English Reading Apprehension Skills among Talented Students in Al Qrayat, Faculty of Education Journal, Asuit University, 33(1): 102-149.

Ikpeze, Chinwe (2004): WebQuests: Usign_Multiple Tasks to Facilitate Critical Thinking. University at Buffalo http://www.scholastic.com

IKPeze, H. \& Boyd, F. (2007). Web - based Inquiry learning: Facilitating thoughtful literacy with Web Quests. 
The Reading Teacher Journal, 60 (7),644-654 April.

Li, H. \& Yang, Y. (2007): The Effectiveness of WebQuest on Elementary School Students' Higher-Order Thinking, Learning Motivation, and English Learning Achievement. In Proceedings of World Conference on Educational Multimedia, Hypermedia and Telecommunications, Chesapeake.

Mahgoub, Y (2014). The Impact of Field Trips on Students' Creative Thinking And. Practices In Arts Education, Journal of American Science, 10(1).

Mitehell C. David ( 2003 ): Using WebQuests as a Guide and Teaching the Use of Search Engines in an 8th Grade Middle School Classroom to Improve Student Learning and Increase Student Comfort When Using the Internet, (A Master's Project), Graduate Division of Wayne State University Detroit, Michigan

Mohammad, Amal. (2017). Effectiveness of Web-based Cognitive Trip in Philosophy Teaching on Development of Future Thinkin Skills and Motivation to Achieve among Secondary Students, Educational Associations Journal of Social Studies, 1(20): 1-70.

Burke, M. Guffey, S., Colter, S., \&Richl, J. (2003), Bio Web Quest : Evaluating The effectiveness of a "WebQuest" model of inquiry in a biology sequence for nonscience majors. Paper presented at the Syllabus , Conference, Palo Alto, CA.

Rushdi, Ibrahim; Saleh, Eman; Al Qadi, Reda; Qayem, Omayma. (2016). Effectiveness of Virtual Instructional Trip on Developing Creative Skills among Vocational Education Students at Faculty of Education. Halwan University, Faculty of Education, 22(1): 269-299.

Zaitoun, Hasan Hussein. (2003). Instructional Trip: New Vision to Develop Teaching-Learning Methods in our Schools, Cairo, World of Books.

Zaitoun, Hasan Hussein. (2003). Thinking Teaching: Application Vision in Developing Thinking Minds, Cairo, World of Books. 